\title{
USING SECTORAL INDEXES TO DISCOUNT THE EXERCISE PRICE OF EMPLOYEE STOCK OPTIONS
}

Agnieszka Majewska, Ph.D, Associate Professor

University of Szczecin

Faculty of Economics and Management

Institute of Finance

Mickiewicza 64, 71-101 Szczecin, Poland

e-mail:magnes@wneiz.pl

Received 24 September 2015, Accepted 22 June 2016

\begin{abstract}
Employee stock options (ESOs) are an instrument in compensating top management of corporations. In the literature, they are described as a variable component of remuneration of a long-term character (Borkowska, 2012). There are six characteristic elements of the ESO: a grant date, the ESO plan duration, employees entitled to receive options, vesting criteria, a vesting period, and an exercise price. The article refers to the exercise price. The remuneration of employees is determined by the option's intrinsic value, i.e. the difference between the current stock price and the exercise price. This difference affects the costs incurred by a company in relation with their incentive stock option plan. In this connection, the exercise price of stock options needs to be analysed.

The literature shows that usually the strike price is equal to the stock market's value at the time the option is granted. The options issued with an exercise price equal to the market value of the company's stock on the date of the grant usually lead to at-the-money options. Walker (2009) mentions that almost all options issued by US firms have been such type of options. Hence, the options with exercise prices less than the prices of the underlying assets have been rarely observed. One of the solutions can be discounting the exercise price by using sectoral indexes, which are sensitive to changes on a particular market.

The purpose of this paper is to address several aspects of specifying the exercise price in ESOs. The research shows how sector indexes can be used to discount it. Using sectoral indexes in determining the exercise price can partly limit the unreasonably high profits from the ESO. The literature does not provide readymade formulas of exercise prices based on specific variables. The aim of the research is to present and apply the formula of the exercise prices in which sectoral indices are used to discount.

The data are from the Warsaw Stock Exchange (WSE) and include those companies that revealed the information concerning their incentive programs in 1999-2013. The relevant data come from annual reports, current reports, supervisory boards' resolutions, and press announcements.
\end{abstract}

Keywords: employee stock options, exercise price, equity compensation instruments 


\section{Introduction}

Employee stock options (ESO) give firm executives and employees the right to buy a certain amount of their own firm's stocks at a pre-specified strike price. They are usually granted to chief executives, finance directors, and other executive directors. The first use of options as a part of remuneration was initial in the USA in the mid-1950s and was limited to senior executives (Lambert et al., 1989). They have been used more widely since the end of the 1990s. In 1998, 97\% of S\&P500 companies granted options to their top executives, as compared to $82 \%$ in 1992 . Also, there was an increase in the value of stock options in the total pay for S\&P 500CEOs - from 25\% in 1992 to 40\% in 1998 (Hall, Murphy, 2002).

There are some inefficiencies generated by employee stock options. One of them is a performance problem. This particularly acute problem is associated with unreasonably high remuneration of executives. It is closely connected with the exercise price. The payoff from exercise options depends on the relation between the strike price and the market price of stocks. The current price of stocks is determined by a situation on the market. The companies do not have a direct influence on this price, but they can set the exercise price in the incentive programs based on the employee stock options.

Hence, the proper value of the exercise price is very significant for an incentive character of option programs. Both too low and too high a price make the programs seem non-motivating for employees. Furthermore, their implementation cost depends on the difference between the current stock price and the exercise price of the option. A considerable difference translates into a higher cost. Thus, it is essential to set the exercise price near the market price. The use of indexes to discount the exercise price allows employees to have a control over the share price. Both in the bull and the bear market, they are not disaffected to work because the exercise price depends on the changes on the market. It also limits their unreasonably high profits. On the grounds that the stock prices change differently in each sector, in this paper it is suggested that the formula of setting the exercise price be based on sectoral indexes. Major indexes of the market are usually used, such as WIG in Poland, S\&P500 in USA, DAX in Germany, etc. There is no mention of sectoral indexes in the literature, therefore, the paper introduces a formula that can be used to set the exercise price of employee stock options. The data are from the Warsaw Stock Exchange (WSE) and include those companies that revealed the information concerning their incentive programs in 1999-2013. The relevant data come from annual reports, current reports, supervisory boards' resolutions, and press announcements. 


\section{A general framework for determining exercise price}

Both in the USA, where ESOs were used as first, and in other countries, there are no regulations on the exercise price of ESOs. Also, the available literature on ESOs does not indicate the methods which should be used. There are only recommendations that the structure of executives remuneration should promote the long-term sustainability of the company, and ensure that remuneration is based on performance (e.g. Commission Recommendation..., 2009).

Hall and Murphy (2000) reported that exercise prices can be set below the grant date stock price, above the grant date stock price, or can be indexed to an industry or market index. Therefore, three types of options can be distinguished: discount, premium, and indexed options. Johnson and Tian (2000) recognize six different types of employee stock options:

a) premium options - the grant price is higher than the market prices at the time of grant. It means that the option is out-of-the-money when granted. It is said to magnify the incentive effect of options;

b) performance-vested options - these options only vest, and hence become exercisable at a specified price above that of the grant price. It is also said to magnify incentive effects;

c) re-priceable options - these options permit re-setting of the exercise price if the stock price falls, and are designed to counter the dis-incentive effects of significant falls in the stock price;

d) purchased options - with these options the recipient pays a proportion of the exercise price at the point of grant with forfeiture of this 'deposit' if the options are not exercised. This locks the recipient into the option, and hence may enhance incentive effects;

e) reload options - with this type of options, the option holder exercises the option with the shares already owned, and then receives new options to replace the shares used in the exercise. This is seen as an implicit way of re-pricing options, and is sometimes used when stock prices have fallen;

f) indexed options - these options have a moving strike price, linked to an industry or market-wide stock index.

This classification does not refer directly to the divisions according to the criterion of the exercise price. Only in the case of premium and indexed options, which are compatible with the division made by Hall and Murphy (2000), the possibilities of the formation of strike prices are indicated. There are no recommendations what type of exercise prices should be applied. Although the practice of using options shows that setting the exercise prices at or near the grant 
date market price maximises the performance of executives. As for the extent of settings, there is no such indication.

When the exercise price is significantly different from the market price, it is necessary to re-set it. ${ }^{1}$ This situation occurs most frequently when the strike price is fixed at a constant value. There are some differences between economies in the case of re-settings of exercise prices. In the USA, this has been a widespread phenomenon in the 21 st century. In Europe, by contrast, re-pricing of options is rather rare.

There is only a very distant US data on re-pricing options. The study of Gilson and Vetsuypens (1992) shows that 25 out of 77 companies had a re-setting of their outstanding options. Saly (1994) examined that after the 1987 crash, 121 out of 187 companies had to renegotiate contracts. Bremner, Sundaram, and Yermack (2000) found out that there were 396 events in 134 companies during the period 1992-1995 which were linked with re-setting of options.

The research of the extent of re-settings show that the change in the exercise price is substantial and is between 40-50\%. Bremner et al (2000) found that the median reduction of the price was $40 \%$. However, in over one third of the cases, the strike price was lowered by $50 \%$. These findings are consistent with those of Gilson and Vetsuypens (1993), who indicated that the average extent of the strike price changes was 50\%, and of Chance et al (1997), who found an average price reduction of $41 \%$. In most cases $(79 \%)$, the re-pricing was associated with fixing a new exercise price which corresponded to the current market price (Bremner et al, 2000). In $19 \%$ of the cases, there was a lowering of the strike price, but still above the market price, and in just over $1 \%$, there was a lowering to below the current market price. Similar results were obtained by Chance, Kumar, and Todd (2000).

It should be emphasized that the re-pricing can be viewed by investors as bad news and the signal that the firm is in distress, because this information can suggest that further falls in share value may occur as well. Furthermore, re-setting can be seen as a reward for a failure instead of restoring incentives. Despite all, Saly (1994) argues that re-pricing of options is optimal after a market downturn to restore incentives. The alternative to the re-pricing can be determining the exercise price as the variable value.

\footnotetext{
1 Re-setting is also used to change the maturity date of options.
} 


\section{The practise of setting the exercise price in Poland}

Taking into consideration the information about the incentive plans implemented by companies listed on the WSE, we can distinguish two methods of the exercise price determination:

- a constant value expressed as a fixed amount,

- a variable value expressed by means of a certain formula.

In Poland, the most popular are the plans where the exercise price is a fixed value. Among the incentive programs adopted in the years 1999-2012 by companies quoted on the WSE, the exercise price was fixed as a constant value in $83 \%$ of them (Majewska, 2013). What is important, in half of the employee stock option plans in the WSE companies, the exercise price was equivalent to the nominal stock price. It is the minimum price at which stocks can be purchased. The practise of allowing employees to buy stocks at the minimum price does not fulfil the purpose of ESO programs. It is usually defined as creating mechanisms motivating their employees to contribute to a longstanding and stable growth of the company value.

The approach where the exercise price is a fixed value has rightly raised criticism against incentive programs. A fixed exercise price of options can deliver very large gains for executives whenever the market is rising, even if the company is underperforming. Rightly, those employee stock options are perceived as the pay without performance (Bebchuk, Fried 2004; Tosi 2005). Where options are viewed as rewards without performance, they have no incentive properties. It is very similar to the situation when options are out-of-the-money. They also may have powerful dis-incentive effects.

One way of preventing executives from generating massive gains from a market performance can be the application of a non-constant value of the strike price in the ESOs programs. Furthermore, it is possible to link the option's exercise price with the situation on the market, by using market index or peer group index. Stock options are, however, rarely indexed to the market.

Only $17 \%$ of the programs adopted by the companies quoted on the WSE used the variable exercise prices. Two general approaches were used: one is an average price in a given period, the other is a market stock price on a certain date, most frequently, on the grant date $(33 \%$ of the programs). In half of the programs with no constant strike price, it was an average price in a given period. The period of 3 months was usually adopted, but there were also examples of 30 and 70 trading days. Very rarely (only in two ESO programs out of 196) were the exercise prices indexed. The most common was the market price discount of 5\% and $10 \%$, although there 
are examples of $40 \%$ and $50 \%$. The need for indexation seems obvious, as Rappaport (1999) showed.

\section{The indexing formula of the exercise price of ESO}

The options with the variable exercise price and discounting used by Polish companies can be compared to the indexed options described by Hall and Murphy (2000). It is difficult to find in the literature ready-made formulas of variable exercise prices with indexing. Hall and Murphy (2000) only say that they are indexed to an industry or market index.

The variable exercise price of the employee stock option with indexing can be classified according to different criteria, including:

- type of a discount: fixed or variable,

- in the case of a variable discount - the type of indexation: based on market conditions (market indexes) or on economic conditions (fundamental indexes),

- number of factors indexing the price: with one or with many indexing factors.

This paper gives a proposal of the variable exercise price with indexing. Sectoral indexes are used which reflect the situation on individual markets, and allow to evaluate the efficiency of investments into businesses in various sectors of economy. Using sectoral indexes to fix a strike price can avoid re-setting and may partly limit the unreasonably high profits from the ESO.

The proposed formula is simple, and thus there is no difficulties in its implementation. The exercise price depends on more than one factor and includes a variable discount represented by sectoral indexes. It is as follows:

$$
X_{i}=\bar{P}(1-\sigma) \frac{I_{t}}{I_{0}}
$$

where:

$\bar{P}$ - a mean from the closing prices for the shares of a company, usually calculated annually during the vesting period,

$\sigma-$ stock prices volatility in the vesting period $(\sigma<1)$,

$I_{t}$ - level of a sectoral index on the last trading date of the vesting period,

$I_{0}-$ level of a sectoral index on the first trading date of the vesting period.

In the proposed formula, the exercise price contrary to the market traded options, is not a constant value. The inclusion of the volatility also allowed to take into account the risk of 
investing in a given company's stocks. It is important that in determining the exercise price the value of the variables during the vesting period is included.

Nowadays, eleven sectoral indexes on the WSE are quoted. The WSE classifies the listed companies into one sector of economy depending on the scope of their business activities in compliance with European Activity Classification and depending on a revenues' structure. A company is put on a sectoral list on the grounds of the opinion given by the members of Index Committee. Weightings in sectoral indices are equal to the weightings in WIG index. The revision of indexes is made quarterly (in March, June, September, and December). Table 1 contains basic information on the sectoral indices on the WSE.

Table 1. Sectoral subindices on the WSE at the beginning of 2015

\begin{tabular}{|l|l|l|c|}
\hline \multicolumn{1}{|c|}{ Macrosector } & \multicolumn{1}{|c|}{ Sector index } & \multicolumn{1}{c|}{ The first day of trading } & \multicolumn{1}{c|}{$\begin{array}{c}\text { Number } \\
\text { of companies }\end{array}$} \\
\hline \multirow{4}{*}{$\begin{array}{l}\text { Industry } \\
\text { (includes 14 sectors) }\end{array}$} & WIG-food & December 31, 1998 & 22 \\
\cline { 2 - 4 } & WIG-chemicals & September 19, 2008 & 7 \\
\cline { 2 - 4 } & WIG-oil\&gas & December 31, 2005 & 26 \\
\cline { 2 - 4 } & WIG-construction & December 31, 1998 & 4 \\
\cline { 2 - 4 } $\begin{array}{l}\text { Finance } \\
\text { (includes 5 sectors) }\end{array}$ & WIG-basic materials & December 31, 2010 & 25 \\
\hline \multirow{4}{*}{$\begin{array}{l}\text { Services } \\
\text { (includes 9 sectors) }\end{array}$} & WIG-banking & December 31, 1998 & 6 \\
\cline { 2 - 4 } & WIG-developers & June 15, 2007 & 25 \\
\cline { 2 - 4 } & WIG-telecom & December 31, 1998 & 15 \\
\cline { 2 - 4 } & WIG-IT & December 31,1998 & 9 \\
\cline { 2 - 4 } & WIG-media & December 31, 2004 & 25 \\
\hline
\end{tabular}

Source: own study.

It is not possible for each ESO program to apply a sectoral index, because out of the 28 sectors present on the WSE, only 11 sectoral subindices are classified. The solution may be taking into account the average value of the indexes from the macrosector to which a company belongs.

\section{Empirical study of using sectoral indexes to discount the exercise price}

The data are from the WSE and include those companies that revealed the information concerning their incentive programs in 1999-2013. In Poland, ESO plans are predominantly established by large companies quoted on the regular stock exchange. The relevant data come from annual reports, current reports, supervisory boards' resolutions, and press announcements. Out of the 394 companies listed at the end of 2013, about a half of the companies have 
touched on the incentive program. Because a part of the programs was only planned, but never implemented, the data were obtained for 144 companies. Figure 1 shows the number of ESO plans enacted in the years 1999-2013 by sectors.

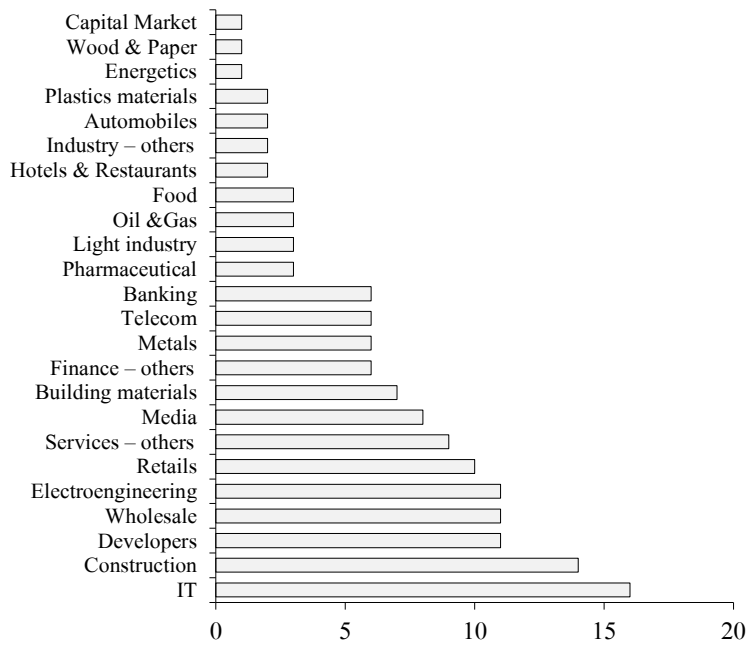

Figure 1. The cumulative number of ESO according to the companies belonging to the sectors of economy at the end of 2013

Source: own study.

Although the ESO plans are not aimed specifically at particular types of a company, they are more widely used in IT sector (approximately $11 \%$ of programs in Poland). The situation is similar in the US and other European countries, e.g. in Germany, Belgium, Finland. The other sector in which the programs are more frequent is construction $(10 \%)$. Basic information about the companies which used sectoral indexes to discount the exercise price in ESOs is shown in Table 2.

The companies that have implemented the ESO plans in total included 24 sectors. However, due to the lack of subindexes for all sectors, the analysis included nine sectors.

In order to evaluate the possibility of using the sectoral indices to discount the exercise price in ESO, it was necessary to define the measure of evaluation. Because the literature indicates that the strike price should not significantly differ from the market price, as a measure, the relation between the current stock price $(\mathrm{S})$ to the exercise price $(\mathrm{X})$ was adopted - $(\mathrm{S} / \mathrm{X})$. The determination of the exercise price, according to equation 1 , has required the designation of the following variables: the average price of shares, the level of sectoral indexes, and the volatility. 
Table 2. Basic information about the companies which used sectoral indexes to discount the exercise price

\begin{tabular}{|c|c|c|c|c|}
\hline Sector decription & $\begin{array}{c}\text { Number } \\
\text { of companies } \\
\text { with ESO plan } \\
\end{array}$ & Sector index & $\begin{array}{c}\text { Number and }(\%) \\
\text { of companies } \\
\text { with ESOs in the index }\end{array}$ & $\begin{array}{c}\text { Share of the value } \\
\text { of companies } \\
\text { in the index }(\%)\end{array}$ \\
\hline $\begin{array}{l}\text { Food (foodstuffs, soft drinks, } \\
\text { and tobacco) }\end{array}$ & 3 & WIG-food & $2[9]$ & 15.184 \\
\hline $\begin{array}{l}\text { Oil \& gas (fuel, gas, and refining } \\
\text { of crude oil) }\end{array}$ & 3 & WIG-oil\&gas & $2[29]$ & 69.735 \\
\hline Construction & 14 & WIG-construction & $10[38]$ & 28.944 \\
\hline Banking & 6 & WIG-banking & $6[43]$ & 53.387 \\
\hline Developers & 11 & WIG-developers & $9[35]$ & 47.016 \\
\hline Telecommunications & 6 & WIG-telecom & $5[83]$ & 96.086 \\
\hline IT and related industries & 16 & WIG-IT & $11[69]$ & 80.957 \\
\hline $\begin{array}{l}\text { Media (press, radio, television, } \\
\text { portals, advertising, and related } \\
\text { industries) }\end{array}$ & 8 & WIG-media & $7[47]$ & 85.112 \\
\hline $\begin{array}{l}\text { Energetic (energetic and related } \\
\text { activities) }\end{array}$ & 1 & WIG-Energy & $1[11]$ & 0.760 \\
\hline
\end{tabular}

Source: own study.

The first two variables are determined by observing the market prices of stocks and sectoral indexes, whereas the volatility should be estimated. Due to the fact that in most of the ESO plans, meeting by employees the loyalty and economic criteria to receive options is verified at the end of the year, the average price of shares was calculated annually. The volatility was determined as a standard deviation based on daily logarithmic rates of return $\left(u_{i}\right)$. Volatility in individual years was calculated by means of the formula:

$$
\sigma=\sqrt{\frac{\sum_{i=1}^{n}\left(u_{i}-\bar{u}\right)}{n-1}} \times \sqrt{250}
$$

It is possible to use other approaches in estimation of volatility: exponential weight moving averages (EWMA), an econometric model, or implied volatility.

The collective results for the exercise prices by sectors are presented in Table 3 and 4 . The basic descriptive statistics were determined for the adopted measure $(\mathrm{S} / \mathrm{X})$.

In most cases, the options with the exercise prices with sectoral indexing were classified as in-the-money options. There were not many cases when the options were deep in-the-money. It is very important because of the keeping incentive effects of ESO plans. The exercise price set as a variable value with sectoral indexing eliminates the risk of a situation when an employee can buy stocks at a price several dozen times cheaper than their market price. In comparison 
Table 3. Characteristics of the exercise prices for sectors - measures of central tendency

\begin{tabular}{|l|r|c|c|c|c|c|c|c|c|c|}
\hline \multirow{2}{*}{ Sector } & \multicolumn{4}{|c|}{ Exercise prices } & \multicolumn{5}{c|}{ Relation between the current stock price } \\
\cline { 2 - 13 } & $\mathrm{n}$ & $\begin{array}{c}\left(\mathrm{n}_{(\mathrm{S}>\mathrm{X})}\right) / \mathrm{n} \\
(\%)\end{array}$ & $\begin{array}{c}\left(\mathrm{n}_{(\mathrm{S}<\mathrm{X})}\right) / \mathrm{n} \\
(\%)\end{array}$ & $\begin{array}{c}\mathrm{N}[\%] \\
0.5 \mathrm{~S}<\mathrm{X}<\mathrm{S} \\
(\%)\end{array}$ & Mean & $\begin{array}{c}\text { Mean } \\
(\mathrm{S}>\mathrm{X})\end{array}$ & $\begin{array}{c}\text { Mean } \\
(\mathrm{S}<\mathrm{X})\end{array}$ & Median & $\mathrm{Q}_{1.4}$ & $\mathrm{Q}_{3.4}$ \\
\hline Food & 2,907 & 60 & 40 & 37 & 1.620 & 2.221 & 0.722 & 1.339 & 0.812 & 1.928 \\
\hline Oil \& gas & 1,508 & 75 & 25 & 37 & 1.969 & 2.376 & 0.754 & 1.608 & 0.997 & 2.723 \\
\hline Construction & 12,591 & 90 & 10 & 42 & 2.165 & 2.322 & 0.773 & 1.947 & 1.280 & 2.907 \\
\hline Banking & 7,223 & 89 & 11 & 69 & 1.552 & 1.656 & 0.733 & 1.434 & 1.175 & 1.854 \\
\hline Developers & 10,686 & 85 & 15 & 46 & 2.205 & 2.470 & 0.751 & 1.652 & 1.177 & 2.747 \\
\hline $\begin{array}{l}\text { Telecommuni- } \\
\text { cations }\end{array}$ & 6,522 & 93 & 7 & 73 & 1.681 & 1.746 & 0.862 & 1.404 & 1.204 & 1.802 \\
\hline IT & 12,540 & 90 & 10 & 53 & 2.579 & 2.780 & 0.717 & 1.726 & 1.346 & 2.630 \\
\hline Media & 5,265 & 91 & 9 & 52 & 1.838 & 1.947 & 0.785 & 1.747 & 1.277 & 2.389 \\
\hline Energetic & 756 & 99 & 1 & 65 & 1.988 & 2.000 & 0.989 & 1.489 & 1.395 & 2.623 \\
\hline
\end{tabular}

Source: own study.

Table 4. Characteristics of a relation between the current stock price to the exercise price $(\mathrm{S} / \mathrm{X})$ - measures of dispersion

\begin{tabular}{|l|c|c|c|c|c|c|c|}
\hline \multicolumn{1}{|c|}{ Sector } & Standard deviation & $\begin{array}{c}\mathrm{V}_{\mathrm{SD}} \\
(\%)\end{array}$ & Semi-interquartile range & $\begin{array}{c}\mathrm{V}_{0} \\
(\%)\end{array}$ & Min & Max & Range \\
\hline Food & 1.147 & 71 & 0.558 & 42 & 0.166 & 5.507 & 5.341 \\
\hline Oil \& gas & 1.204 & 61 & 0.863 & 54 & 0.334 & 6.124 & 5.789 \\
\hline Construction & 1.149 & 53 & 0.813 & 42 & 0.345 & 9.478 & 9.133 \\
\hline Banking & 0.590 & 38 & 0.339 & 24 & 0.294 & 4.191 & 3.897 \\
\hline Developers & 1.636 & 74 & 0.785 & 47 & 0.166 & 10.894 & 10.728 \\
\hline Telecommunications & 0.912 & 54 & 0.299 & 21 & 0.447 & 7.148 & 6.675 \\
\hline IT & 3.446 & 134 & 0.642 & 37 & 0.090 & 49.888 & 49.797 \\
\hline Media & 0.677 & 37 & 0.556 & 32 & 0.324 & 3.795 & 3.471 \\
\hline Energetic & 0.907 & 46 & 0.614 & 41 & 0.975 & 4.060 & 3.085 \\
\hline
\end{tabular}

Source: own study.

to the practice used by the WSE companies, this situation was slightly different. The optimal contract is said to be the one that finds a balance between incentives effects and risk aversion. Thus the strike price should not differ much from the current stock price. On the other hand, the main goal of stock option plans is the recruitment and retention of skilled employees, and it does not occur when the company grants them out-of-the-money options. This situation often occurs when market prices fall. The protection from the turbulence on the market is possible by using sectoral indexes to discount the exercise price. 


\section{Conclusions}

Employee stock options are used primarily to provide incentives. Therefore, it is important to properly define the exercise price. In the proposed formula the exercise price, contrary to the market traded options, is not a constant value. The inclusion of the volatility also allowed to take into account the risk of investing in a given company's stocks. It is important that in determining the exercise price, the value of variables during the vesting period is included.

The formula of the exercise price set out in the article is consistent with the European Commission's recommendations. They say that the structure of directors' remuneration should promote the long-term sustainability of the company, and ensure that remuneration is based on performance (Commission Recommendation..., 2009).

\section{References}

Bebchuk, L.A., Fried, J.M. (2004). Pay without performance: the unfulfilled promise of executive compensation. London: Harvard University Press.

Borkowska, S. (2012). Skuteczne strategie wynagrodzeń-tworzenie i zastosowanie. Warszawa: Wolters Kluwer Polska.

Brenner, M., Sundaram, R., Yermack, D. (2000). Altering the terms of executive stock options. Journal of Financial Economics, 57, 103-128.

Chance, D., Kumar, R., Todd, R. (2000). The “repricing” of executive stock options. Journal of Financial Economics, 57, 129-154.

Commission Recommendation of 30 April 2009 complementing Recommendations 2004/913/ EC and 2005/162/EC as regards the regime for the remuneration of directors of listed companies. Official Journal of the European Union.

Gilson, S., Vetsuypens, M. (1993). CEO compensation in financially distressed firms: an empirical analysis. Journal of Finance, 48, 425-458.

Hall, B.J., Murphy, K.J. (2000). Optimal exercise price for executive stock options. American Economic Review, 90 (2), 209-214.

Hall, B.J., Murphy, K.J. (2002). Stock options for undiversified executives. Journal of Accounting and Economics, 33, 3-42, 209.

Johnson, S., Tian, Y. (2000). Indexed executive stock options. Journal of Financial Economics, $57,35-64$. 
Lambert, R.A., Lanen, W.N., Larcker, D.F. (1989). Executive stock option plans and corporate dividend policy. Journal of Financial and Quantitative Analysis, 24, 409-425.

Majewska, A. (2013). Instrumenty pochodne jako narzędzia wspomagajace zarzadzanie ryzykiem w przedsiębiorstwie. Szczecin: Wydawnictwo volumina.pl.

Rappaport, A. (1999). New Thinking on how to link executive pay with performance. Harvard Business Review, March/April, 91-101.

Saly, J. (1994). Repricing executive stock options in a down market. Journal of Accounting and Economics, 19, 325-356.

Tosi, H.L. (2005). Pay without performance: The unfulfilled promise of executive compensation. Administrative Science Quarterly, 50, 483-487.

Walker, D.I. (2009). The non-option: understanding the dearth of discounted employee stock options. Boston University Law Review, 89, 1505-1563. 